\title{
\begin{tabular}{l|l|l} 
jurnal & Jurnal Kependidikan Dasar & $\begin{array}{l}\text { volume 6 } \\
\text { Nomor } 2 \\
\text { Tahun } 2021\end{array}$ \\
ibriez & Islam Berbasis Sains & ibriez
\end{tabular}
}

\section{EVALUASI PELAKSANAAN PROGRAM PENGUATAN PENDIDIKAN KARAKTER (PPK) SELAMA PANDEMI COVID-19 DI SEKOLAH DASAR}

\author{
Lisa Retnasari' ${ }^{1}$, Yayuk Hidayah ${ }^{2}$, Nufikha Ulfah ${ }^{3}$, Donita Gustika Siraten ${ }^{4}$ \\ 1,2,4Universitas Ahmad Dahlan, ${ }^{3}$ Institut Teknologi Sumatera \\ Surel: nufikha.ulfah@staff.itera.ac.id
}

\begin{abstract}
Abstrak
Penelitian ini bertujuan untuk mendeskripsikan pelaksanaan program penguatan pendidikan karakter di sekolah dasar. SD Muhammadiyah Karangkajen terdapat program PPK berbasis satuan tugas (satgas) khusus PPK untuk membentuk leader school by student to student dalam mengimplementasikan dan memanifestasikan nilai-nilai karakter ke dalam berbagai aspek kehidupan. Penelitian ini menggunakan metode evaluasi dengan pendekatan kualitatif dan model CIPP (Context, Input, Process, Product). Teknik pengumpulan data melalui wawancara, observasi dan dokumentasi. Teknik analisis data melalui reduksi data, penyajian data, dan penarikan kesimpulan. Hasil penelitian ini (1) tahapan konteks (context) visi dan misi, kebijakan sekolah, dan peluang yang dimanfaatkan sesuai antara yang dicanangkan oleh pemerintah dengan yang diimplementasikan; (2) tahapan masukan (input) program PPK selama pandemi berjalan dengan adanya koordinasi antara guru pendamping PPK, wali kelas, dan peserta didik. Sarana dan prasarana, pembiayaan dana, dan kondisi lingkungan sosial sekolah dan masyarakat sudah mendukung pelaksanaan program PPK; (3) tahapan proses (process) rincian pelaksanaan program PPK selama pandemi sesuai dengan realita di lapangan; (4) tahapan produk (product) peserta didik selama pandemi lebih ditonjolkan nilai religiusitas dan kemandirian.
\end{abstract}

Kata Kunci: evaluasi, PPK, pandemi covid 19, sekolah dasar

\begin{abstract}
This study aims to describe the implementation of character education strengthening programs in elementary schools. At SD Muhammadiyah Karangkajen there is a special task force unit (Satgas) based PPK program to form school by student to student leaders in implementing and manifesting character values into various aspects of life. This research uses an evaluation method with a qualitative approach and the CIPP (Context, Input, Process, Product) model. Data collection techniques through interviews, observation and documentation. Data analysis techniques through data reduction, data presentation, and drawing conclusions. The results of this study (1) the stages of the context (context) of the vision and mission, school policies, and opportunities that are utilized are in accordance with those announced by the government and those that are implemented; (2) the input stages of the PPK program during the pandemic are carried out with coordination between PPK assistant teachers, homeroom teachers, and students. Facilities and infrastructure, funding of funds,
\end{abstract}


and conditions of the school and community social environment have supported the implementation of the KDP program; (3) the details of the process of implementing the KDP program during the pandemic are in accordance with the reality on the ground; (4) the stages of the product (product) of students during the pandemic emphasize the value of religiosity and independence.

Keywords: evaluation, PPK, pandemic covid 19, elementary school

\section{A. PENDAHULUAN}

Pada awal tahun 2020 dunia dihebohkan dengan kemunculan penyakit menular bernama Coronavirus Disease 2019 (Covid-19). Coronavirus merupakan virus jenis baru yang dapat menyebabkan penyakit infeksi saluran pernapasan pada manusia, mulai dari flu biasa, MERS (Middle East Respiratory Syndrome), dan SARS (Severe Acute Respiratory Syndrome) yang pertama kali ditemukan di Wuhan, China pada Desember 2019.1 Dampak dari pandemi Covid-19 ini begitu dirasakan pada bidang pendidikan karena adanya pembatasan interaksi sosial untuk menanggulangi penyebaran virus. Hal ini menyebabkan pemerintah harus membuat suatu kebijakan yang memungkinkan agar pembelajaran tetap dapat dilaksanakan selama pembatasan interaksi sosial ini.

Pemerintah akhirnya membuat kebijakan agar proses pembelajaran dilakukan secara online (daring) akan tetapi sulit memberikan pendidikan karakter kepada peserta didik. $^{2}$ menyatakan bahwa guru harus melakukan observasi secara langsung untuk mengevaluasi perkembangan etika, tanggungjawab dan karakter peserta didik. Dengan dilakukannya proses pembelajaran secara online menyebabkan guru tidak dapat mengobservasi peserta didik secara langsung. Oleh karena itu, guru dituntut agar selalu kreatif dalam membuat metode evaluasi untuk mengetahui perkembangan serta membantu membentuk karakter peserta didik meskipun melalui pembelajaran secara online.

Pendidikan karakter adalah suatu proses penerapan nilai-nilai moral dan agama pada peserta didik. ${ }^{3}$ Pembentukan karakter yang baik pada peserta didik sangat bergantung pada penanaman pendidikan karakter melalui pembiasaan rutin yang dilakukan di sekolah. Melalui pembiasaan ini maka akan tertanam dengan baik nilai-nilai karakter dalam diri peserta didik. Hal ini sejalan dengan pendapat Wibowo $^{4}$ yang mengemukakan bahwa nilai-nilai karakter harus ditumbuhkan melalui pembiasaan seharihari di sekolah dengan menjadikannya budaya sekolah agar mencapai keberhasilan pendidikan karakter itu sendiri. Pendidikan karakter sebagai budaya sekolah

\footnotetext{
${ }^{1}$ Kementrian Kesehatan RI, "Kesiapsiagaan Menghadapi Infeksi COVID-19," https://www.kemkes.go.id/article/view/20030400008/FAQ-Coronavirus.html, 2020.

2 I Wayan Eka Santika, "Pendidikan Karakter pada Pembelajaran Daring," Indonesian Values and Character Education Journal 3, no. 1 (2020): 8-19.

3 Dini Palupi Putri, "Pendidikan Karakter dada Anak Sekolah Dasar di Era Digital," AR-RIAYAH: Jurnal Pendidikan Dasar, 2018, https://doi.org/10.29240/jpd.v2i1.439.

4 Wibowo Agus, "Pendidikan Karakter: Strategi Membangun Karakter Bangsa Berperadaban," Yogyakarta: Pustaka Pelajar, 2012.
} 
mempermudah sekolah untuk mencapai keberhasilan dalam membentuk karakter yang baik pada peserta didik.

Guru berperan penting dalam membantu membentuk watak peserta didik dengan cara menanamkan kebiasaan dan memberi contoh yang baik kepada peserta didik. Undang-Undang Nomor 20 tahun 2003 tentang Sistem Pendidikan Nasional (SPN) telah menegaskan bahwa:

"Pendidikan Nasional berfungsi mengembangkan kemampuan dan membentuk watak serta peradaban bangsa yang bermartabat dalam rangka mencerdaskan kehidupan bangsa, bertujuan untuk berkembangnya potensi peserta didik agar menjadi manusia yang beriman dan bertakwa kepada Tuhan Yang Maha Esa, berakhlak mulia, sehat, berilmu, cakap, kreatif, mandiri dan menjadi warga negara yang demokratis serta bertanggung jawab"5

Pembentukan watak peserta didik harus benar-benar dijalankan dengan maksimal agar peserta didik menjadi manusia yang berakhlak mulia dan berkarakter sesuai dengan tujuan pendidikan nasional.

Penguatan Pendidikan Karakter (PPK) disampaikan oleh Presiden Republik Indonesia sebagai bagian dari Gerakan Nasional Revolusi Mental (GNRM). Melalui Peraturan Presiden Republik Indonesia No. 87 tahun 2017 tentang implementasi PPK pada pasal 1 ayat 1 yang menyatakan bahwa PPK adalah gerakan pendidikan untuk memperkuat karakter peserta didik melalui harmonisasi olah hati, olah rasa, olah pikir, dan olah raga dengan pelibatan dan kerjasama antara satuan pendidikan, keluarga, dan masyarakat. ${ }^{6}$ menyatakan bahwa PPK menjadi asas dan roh bagi peningkatan kualitas pendidikan dalam GNRM. Gerakan PPK meletakkan nilai-nilai karakter sebagai ukuran terdalam pendidikan yang maju dan beradab. Nilai-nilai karakter tersebut diantaranya adalah religius, nasionalisme, kemandirian, gotong royong, dan integritas. ${ }^{7}$ Kelima nilai karakter ini harus dikembangkan untuk membentuk karakter peserta didik.

Berdasarkan data dari Komisi Perlindungan Anak Indonesia (KPAI) diketahui karena merosotnya pendidikan karakter di sekolah dasar pada tahun 2020 terdapat sekitar $30,65 \%$ dari total pengaduan (sekitar 4.734 aduan) telah terjadi degradasi moral pada peserta didik. Hal ini disebabkan karena masih minimnya penerapan nilai-nilai pendidikan karakter di sekolah dasar. Oleh karena itu, pemerintah berusaha untuk memperbaiki karakter bangsa Indonesia sesuai dengan Agenda Nawacita No. 8 yang diusung oleh Presiden Joko Widodo yaitu melakukan revolusi karakter bangsa melalui kebijakan penataan kembali kurikulum pendidikan nasional.

\footnotetext{
${ }^{5}$ Depdiknas, Undang-Undang No. 20 Tahun 2003 tentang Sistem Pendidikan Nasional (Jakarta, 2003).

${ }^{6}$ Koesoema D, Pendidikan Karakter Berbasis Kelas (Yogyakarta: PT Kanisius, 2018).

7 Ilham Nur Sujatmiko, Imron Arifin, dan Asep Sunandar, “Penguatan Pendidikan Karakter di SD," Jurnal Pendidikan: Teori, Penelitian, dan Pengembangan, 2019.
} 
Pelaksanaan kurikulum di sekolah sebaiknyadilaksanakan berkesinambungan dengan penerapan nilai-nilai PPK. ${ }^{8}$ Penerapan nilai-nilai utama PPK dapat diintegrasikan dalam proses pembelajaran untuk menumbuhkan dan menguatkan pengetahuan, menanamkan kesadaran, dan mempraktikkan nilai-nilai utama PPK. Melaksanakan kurikulum dengan menerapkan nilai-nilai utama PPK bertujuan melahirkan pribadi peserta didik yang cerdas dan berkarakter. Hal ini sejalan dengan pendapat Anggraeni \& Soedjono ${ }^{9}$ yang mengemukakan, tujuan nasional bangsa untuk mencerdaskan kehidupan bangsa melalui pendidikan dengan mencetak generasi-generasi yang memiliki kecerdasan baik spiritual, kepribadian dan keterampilan. Kecerdasan seseorang tidak hanya dinilai dari segi pengetahuan saja melainkan dari kesinambungan pengetahuan, spiritual, kepribadian serta keterampilan seseorang.

Sayangnya pengimplementasian PPK saat ini masih begitu rendah. Hal ini terlihat dari banyaknya terjadi perilaku kekerasan dalam lingkungan pendidikan dan masyarakat, kejahatan seksual, tawuran pelajar, pergaulan bebas hingga kecenderungan narkoba. ${ }^{10}$ Rendahnya pengimplementasian PPK melalui pendidikan formal, informal, dan nonformal dapat menyebabkan terjadinya degradasi kualitas moral pada anak. PPK melalui lingkungan masyarakat memberikan pengaruh yang cukup besar pada perkembangan karakter dan moral anak. Meski demikian masih ada beberapa masyarakat yang mengesampingkan hal tersebut. Yuliana et al.,11 menyatakan, sikap atau karakter dan moral sekarang ini sudah dikesampingkan oleh masyarakat. Perlu adaya kesadaran bahwa PPK akan terlaksana dengan baik melalui kerjasama yang sinergis dan berkesinambungan antara lingkungan pendidikan, keluarga, dan masyarakat.

Berkembangnya permainan digital (game online) sekarang ini juga mempengaruhi pengimplementasian PPK. ${ }^{12}$ Hal ini disebabkan karena konten yang disajikan dalam permainan digital (game online) sarat dengan kekerasan. Konten-konten tersebut bertentangan dengan pendidikan karakter yang senantiasa mengajarkan kesantunan, kelembutan, kedamaian, dan cinta sesama. Permainan digital (game online) menjadi salah satu penyebab degradasi kualitas moral pada anak karena dikhawatirkan anak dapat meniru perilaku dalam konten-konten game online yang mereka mainkan.

Minimnya pembiasaan nilai-nilai karakter di lingkungan sekolah juga mempengaruhi kurangnya implementasi PPK dikarenakan minimnya contoh budaya baik yang terintegrasi langsung dengan perilaku peserta didik di lingkungan sekolah. Dalam

\footnotetext{
8 Desy Nurlaida Khotimah, "Implementasi Program Penguatan Pendidikan Karakter ( PPK ) melalui Kegiatan 5s Di Sekolah Dasar," Ilmiah Kependidikan 2, No. 1 (2019): 28-31.

${ }^{9}$ Rise Aditya Anggraeni dan Soedjono Soedjono, "Implementasi Program Penguatan Pendidikan Karakter (Ppk) di SDN Mangkang Wetan 02 Kota Semarang," Gema Publica, 2018, https://doi.org/10.14710/gp.3.1.2018.36-45.

${ }^{10}$ Kemendikbud, Kajian dan Pedoman Penguatan Pendidikan Karakter (Jakarta: Kementerian Pendidikan dan Kebudayaan, 201.

11 Nurbaiti, "Kecanduan Bermain Game Online dan Hubungannya dengan Pendidikan Karakter Islami Siswa (Studi di SD Azhari Cilandak Jakarta)" 3, No. 1 (2020): 55-67.

${ }^{12}$ Nurbaiti.
} 
konsep dan pedoman penguatan Pendidikan karakter yang disusun Kemendikbud tahun 201713, dijelaskan bahwa PPK merupakan gerakan memperkuat karakter melalui harmonisasi olah hati, olah pikir, olah rasa dan olah raga sesuai dengan falsafah hidup Pancasila. Onde et al., ${ }^{14}$ menjelaskan bahwa olah hati (etik) merupakan individu yang memiliki kerohanian mendalam, beriman dan bertaqwa. Olah rasa (estetis) merupakan individu yang memiliki integritas moral, rasa kesenian dan berkebudayaan. Olah pikir (literasi) merupakan individu yang memiliki keunggulan akademis sebagai hasil pembelajar sepanjang hayat. Olah raga (kinestetik) merupakan individu yang sehat dan mampu berpartisipasi aktif sebagai warga negara.

Program PPK di sekolah dasar akan sangat membantu dalam pembentukan karakter peserta didik. Sejalan dengan pendapat Hamid15 yang menyatakan, "sekolah (pendidikan) merupakan salah satu tempat yang strategis dalam pembentukan karakter selain di keluarga dan masyarakat". Salah satu contoh penerapan yang bisa dilakukan adalah progam PPK berbasis pembentukan satuan tugas (satgas) khusus untuk membentuk leader school by student to student. Muryaningsih \& Mustadi menyatakan, usaha penyeimbangan pendidikan karakter dengan pembentukan kompetensi diterapkan melalui kurikulum 2013 yang berorientasi pada ketercapaian tiga kompetensi lulusan yaitu sikap, pengetahuan, dan keterampilan secara seimbang. ${ }^{16}$

Selama ini, progam PPK masih berfokus pada kegiatan pembelajaran di kelas, pembelajaran pada mata pelajaran tertentu dan kegiatan ekstrakurikuler yang semua terfokus dari guru bukan dari siswa, untuk siswa dan kembali ke siswa. Faktor lain yang menyebabkan program PPK masih belum berkembang dengan pesat adalah masih minimnya pemahaman guru tentang PPK di Sekolah Dasar. Wulandari \& Andhiarni ${ }^{17}$ mengemukakan, rendahnya usaha guru untuk memperkuat karakter peserta didik dapat berpengaruh pada potensi karakter yang dimiliki peserta didik. Dengan adanya progam PPK berbasis pembentukan satgas khusus PPK dapat membantu guru menjadikan peserta didik lebih bertanggungjawab karena mereka memiliki kewajiban atas diri mereka sendiri dan teman sebaya.

Satgas khusus PPK ini merupakan sekelompok peserta didik yang dibentuk oleh guru yang mempunyai tugas dan tanggung jawab untuk mengawal dan melaksanakan nilai

13 Kemendikbud, Konsep dan Pedoman Penguatan Pendidikan Karakter (Jakarta: Kementerian Pendidikan dan Kebudayaan, 2017).

14 Mitrakasih La ode Onde et al., "Integrasi Penguatan Pendidikan Karakter (Ppk) Era 4.0 pada Pembelajaran berbasis Tematik Integratif di Sekolah Dasar," Jurnal Basicedu, 2020, https://doi.org/10.31004/basicedu.v4i2.321.

15 A Hamid, Pendidikan Karakter Berbasis Pesantren: Pelajar dan Santri Dalam Era IT \& Cyber Culture (Surabaya: IMTIYAZ, 2017).

16 Sri Muryaningsih dan Ali Mustadi, "Pengembangan RPP Tematik-Integratif untuk Meningkatkan Karakter Kerja Keras di Kelas 1 SD N 2 Sokaraja Tengah,” Jurnal Prima Edukasia, 2015, https://doi.org/10.21831/jpe.v3i2.6146.

17 La Hasirun, Djoko Suryo, dan Taat Wulandari, "From Papua hnonationalism to Indonesian Nationalism: A Historical Study," in Proceedings of the 1st International Conference on Science and Technology for an Internet of Things (European Alliance for Innovation (EAI), 2018). 
karakter (religius, nasionalis, kemandirian gotong royong dan integritas) yang terimplementasi dalam pembagian kerja di lingkungan sekolah yang bersifat substansional. Menurut Hasibuan ${ }^{18}$ pembagian kerja adalah informasi tertulis yang menguraikan tugas dan tanggung jawab, kondisi pekerjaan, hubungan pekerjaan, dan aspek-aspek pekerjaan pada suatu jabatan tertentu dalam organisasi. Pembagian kerja ini sangat penting dalam suatu organisasi agar segala aktivitas dapat dibagi secara merata kepada setiap anggota organisasi sesuai dengan kemampuan masing-masing. ${ }^{19}$ Dengan dibentuknya satgas khusus PPK maka pembagian kerja peserta didik akan terurai dengan jelas dan terperinci dalam komunitas satuan pendidikan khususnya dalam program PPK.

Penelitian terdahulu mengenai program PPK berbasis student leader menunjukkan bahwa pengimplementasian karakter dapat berjalan dengan baik, namun sejauh ini belum ada yang dilakukan melalui satgas khusus PPK. Seperti dalam penelitian Windasari \& Haq 20 yang menunjukkan bahwa program PPK berbasis student leader berjalan dengan baik. Hal ini ditunjukkan dengan kesungguhan dan kerjasama stakeholder agar pendidikan karakter dapat terimplementasi melalui program Ready to be a Leader. Faktor penghambat dalam program ini yaitu kurangnya percaya diri dari peserta didik dan kurangnya peran atau kerjasama wali murid. Berdasarkan Penelitian terdahulu tersebut maka keterbaruan penelitian ini adalah mengenai evaluasi pelaksanaan program penguatan pendidikan karakter (PPK) khususnya selama pandemi Covid-19 di Sekolah Dasar.

SD Muhammadiyah Karangkajen merupakan salah satu sekolah yang menjalankan program PPK melalui pembentukan satgas khusus PPK. Satgas khusus PPK yang tengah dijalankan ini menerapkan model berbasis dari, oleh dan untuk peserta didik. Kegiatan dari program ini merupakan kegiatan yang berbasis kepemimpinan peserta didik (student leader) dalam mengimplementasikan dan memanifestasikan nilai-nilai karakter ke dalam berbagai aspek kehidupan. Dibentuknya satgas khusus PPK ini untuk memperkuat karakter yang ada pada diri peserta didik. Namun, dikarenakan pandemi Covid-19 saat ini menyebabkan program PPK berbasis satgas khusus PPK di SD Muhammadiyah Karangkajen diberhentikan untuk sementara. Hal ini dikarenakan pelaksanaan program PPK berbasis satgas khusus PPK ini dijalankan di sekolah dengan bimbingan dan arahan dari guru pendamping satgas khusus PPK. Pelatihan-pelatihan yang diberikan oleh guru pelatih satgas khusus PPK pada peserta didik yang menjadi satgas khusus PPK pun juga dilaksanakan di sekolah. Tentunya dengan adanya pandemi Covid-19 saat ini menyebabkan SD Muhammadiyah Karangkajen harus mencari cara untuk tetap dapat mengimplementasikan dan memanifestasikan program PPK pada peserta didik agar tetap terlaksana meskipun terkendala pembatasan sosial dan pembelajaran online. Artikel ini

${ }^{18}$ Hasibuan, Manajemen Sumber Daya Manusia (Jakarta: Bumi Aksara, 2007).

${ }^{19}$ A. Hikmawati, H. Sawiji, and A. Subarno, "Pembagian Kerja, Motivasi Kerja dan Kemampuan Kerjasama Terhadap Efektivitas Kerja Pegawai," Jurnal Pendidikan Administrasi Perkantoran, 2012.

20 Dewi Windasari and Mohammad Syahidul Haq, "Program Ready To Be a Leader Di Sd Al-Falah Darussalam Tropodo Sidoarjo" 08, No. 20 (2020): 267-78. 
terfokuskan pada bagaimana evaluasi pelaksanaan program PPK di SD Muhammadiyah Karangkajen selama pandemi Covid-19?

\section{B. METODE PENELITIAN}

Penelitian ini menggunakan metode evaluasi dengan pendekatan kualitatif dan model CIPP (Context, Input, Process, Product). Teknik pengumpulan data diperoleh melalui wawancara, observasi, dan dokumentasi. Data penelitian yang telah didapatkan kemudian dianalisis dengan cara mereduksi data sesuai dengan kebutuhan dari fokus penelitian. Data yang telah direduksi kemudian disajikan dan ditarik kesimpulan. Informan kunci dalam penelitian ini adalah kepala sekolah dan guru pendamping PPK.

\section{HASIL DAN PEMBAHASAN}

\section{Hasil}

Berdasarkan hasil penelitian yang telah dilakukan, diketahui bahwa terdapat perbedaan pada masing-masing poin mengenai evaluasi pelaksanaan program penguatan pendidikan karakter (PPK) selama pandemi Covid-19 di Sekolah Dasar. Perbedaan tersebut dapat peneliti jabarkan sebagai beirkut ini:

Hampir sama pada masing-masing poin.

\section{Evaluasi Konteks (Context)}

Konteks visi dan misi SD Muhammadiyah Karangkajen berusaha menciptakan anakanak yang berprestasi, cerdas dan berakhlak mulia. Meski terkendala dengan adanya pandemi covid-19 tetapi sekolah tetap berusaha mewujudkan kegiatan belajar mengajar yang berkualitas dimana aktivitas akademik tetap berkesinambungan dengan bidang agama serta pembiasaan-pembiasaan baik saat sekolah offline tetap terwujud selama pembelajaran online (di lingkungan rumah peserta didik).

Sekolah berusaha mewujudkan budaya yang berkarakter dengan menciptakan suasana sekolah yang mendukung program pendidikan karakter yang mereka miliki yaitu satuan tugas (satgas) khusus PPK dimana seluruh kerangka sekolah seperti kepala sekolah, staf, guru dan peserta didik bekerjasama mewujudkan program tersebut agar menjadi budaya sekolah yang tetap terus berjalan.

Pengembangan nilai-nilai Penguatan Pendidikan Karakter (PPK) yang meliputi bidang religiusitas, nasionalisme, kemandirian, gotong-royong dan integritas diimplementasikan melalui proses belajar mengajar secara daring serta melalui pembiasaan-pembiasaan yang bisa dilakukan peserta didik di rumah masing-masing.

Selama pandemi ini kelima nilai karakter tersebut tidak dapat diimplementasikan seluruhnya karena tidak adanya pembelajaran tatap muka dan satgas khusus PPK pun juga 
diberhentikan sehingga nilai PPK yang lebih ditonjolkan selama pembelajaran online ini yaitu nilai religiusitas dan kemandirian saja.

SD Muhammadiyah Karangkajen mengembangkan pendidikan karakter berlandaskan pada Undang-Undang Sisdiknas No. 20 Tahun 2003 Pasal 3 tentang pengembangan karakter, Pepres No. 17 Tahun 2010, dan Kepres No. 87 Tahun 2017 tentang penguatan pendidikan karakter. Kepala sekolah kemudian menurunkan SK pembentukan tim PPK Nomor 35/KEP/III.4.AU/107/J/2020.

Peluang dari terlaksananya program PPK ini agar peserta didik terbiasa diarahkan dengan karakter-karakter PPK sehingga bisa menjadi peserta didik yang berprestasi, menjadi pembiasaan baik sampai kapan pun, menjadi habit (karakter) sampai peserta didik melanjutkan kejenjang SMP-SMA-Kuliah, serta nantinya dapat diterapkan dalam kehidupan sehari-hari peserta didik hingga mereka dewasa kelak.

\section{Evaluasi Masukan (Input)}

Program PPK berbasis satgas di SD Muhammadiyah Karangkajen sudah berjalan sekitar 3 sampai 4 tahun dimana mulanya pelan-pelan dibentuk untuk melengkapi ketugasan dan tupoksi dari satgas tersebut hingga saat ini telah menjadi budaya sekolah (brand school) di SD Muhammadiyah Karangkajen.

Satgas-satgas khusus PPK yang dibentuk, yaitu: 1) Satgas Bima-Sinta dimana ketugasannya terkait dengan kegiatan keagaman (religiusitas); 2) Polisi Cilik (Polcil) dan Patroli Keamanan Sekolah (PKS) (nasionalisme); 3) Hizbul Wathan (HW) Komando Pasukan Terlatih (Kopatih) (kemandirian); 4) Satgas Penegak Kebersihan (SPK) (gotongroyong); dan Dokter Kecil (Dokcil) dan Satgas Literasi (integritas).

Satgas-satgas ini memiliki ketugasannya masing-masing yang dikoordinasi oleh koordinator tiap satgas yaitu guru pendamping PPK. Anggota tiap satgas sendiri yaitu peserta didik kelas IV, V, dan VI yang sebelumnya telah diseleksi dan dilatih.

Guru pendamping satgas khusus PPK berjumlah sekitar 15-20 guru karyawan. Peran guru pendamping dalam pelaksanaan program PPK selama pandemi adalah.

Karena wali kelas sebagai tokoh sentral dan yang sering bertemu dengan peserta didik dalam artian memberi tugas dan materi sehingga wali kelas memiliki andil yang cukup besar dalam penerapan nilai-nilai karakter pada peserta didik selama pandemi covid-19.

Selama pandemi ini karena peserta didik lebih banyak belajar secara mandiri di rumah sehingga karakter yang lebih ditonjolkan adalah kemandirian dan nilai karakter yang lainnya tergantung dari materi yang guru sampaikan saat pembelajaran daring.

Peserta didik yang dulunya merupakan anggota satgas khusus PPK selalu berusaha untuk menjalankan nilai-nilai PPK dengan baik sesuai dengan tanggungjawabnya masingmasing serta menjadi contoh yang baik untuk teman-teman di kelasnya meskipun tidak semaksimal saat sekolah offline. Beberapa peserta didik selalu berusaha untuk selalu bangun pagi, mandi pagi dan melaksanakan sholat dhuha sebelum melakukan pembelajaran online. 
Untuk sarana dan prasarana dalam pelaksanaan program PPK di SD Muhammadiyah Karangkajen sudah dapat mendukung dan layak digunakan dalam pelaksanaan program PPK seperti tersedia ruang belajar (ruang kelas), media belajar (alat peraga), bahan ajar, perpustakaan, ruang IT (komputer), ruang ibadah (musholla), lapangan olahraga, kantin, UKS, parkiran, taman dan kebun sekolah, tempat sampah pada setiap ruang kelas, toilet, dan tempat cuci tangan (wastafel).

Untuk sarana dan prasarana dalam pelaksanaan program PPK berbasis satgas juga sudah mendukung dimana terdapat pos khusus untuk setiap satgas dan setiap satgas memiliki seragam atribut khusus.

Sumber utama pembiayaan program PPK berasal dari dana kegiatan siswa. Anggaran dana dan penggunaan dana program PPK selama pandemi belum sesuai dengan apa yang direncanakan sehingga sekolah mencari solusi dengan cara mengkomunikasikan dengan wali murid untuk memberikan sumbangan dana untuk program PPK. Hal ini dilakukan karena tidak adanya bantuan dana dari pemerintah untuk program PPK di SD Muhammadiyah Karangkajen.

Rincian rencana anggaran belanja terkait program PPK disusun oleh koordinator masing-masing satgas PPK atau guru penanggungjawab tiap satgas PPK yang kemudian mengajukan proposal untuk meminta dana pada bendahara sekolah sesuai anggaran yang dibutuhkan.

Kondisi lingkungan di SD Muhammadiyah Karangkajen sudah mendukung dalam pelaksanaan program PPK. Program PPK ini sendiri dimulai sejak tahun 2017 sehingga sudah disiapkan dengan baik. Selain itu dimasa pandemi ini SD Muhammadiyah Karangkajen ditunjuk sebagai sekolah percontohan pembelajaran tatap muka terbatas.

Satgas PPK mulai dari Satgas Bima Sinta (religiusitas), Satgas PKS dan Pocil Serciba (nasionalisme), Satgas Kopatih (kemandirian), Satgas Penegak Kebersihan (gotong royong), dan Satgas Dokter Kecil sangat didukung oleh kondisi lingkungan sekolah dan masyarakat setempat yang mempermudah pelaksanaan program PPK agar tetap berjalan dengan maksimal.

\section{Evaluasi Proses (Process)}

Pelaksanaan program PPK selama pandemi covid-19 yaitu dengan menyisipkan nilai-nilai karakter dalam kegiatan pembelajaran daring setiap harinya. Meskipun dalam menerapkan nilai-nilai karakter melalui pembelajaran daring tidaklah mudah. Hal ini karena kegiatan PPK lebih condong ke praktik bukan teori sehingga lebih mudah jika dilakukan saat pembelajaran tatap muka. Meski demikian.

Pelaksanaan program PPK sebelumnya berada langsung dibawah bimbingan dan pelatihan dari kepolisian maupun kepanduan HW. Setelah pandemi pelaksanaan program PPK ini belum bisa dilaksanakan secara maksimal mengingat terbatasnya aktivitas yang bisa dilakukan karena tidak bisa bertatap muka langsung dengan peserta didik.

Pelaksanaan program PPK selama pandemi yaitu dengan melakukan pembiasaanpembiasaan yang bisa diterapkan di rumah sebelum memulai pembelajaran daring seperti: 
sholat dhuha terlebih dahulu, mandi pagi, dan menyiapkan buku sebelum memulai Zoom. Guru juga sebelum memulai Zoom sudah harus memberikan bahan ajar (LKS, materi pdf atau Power Point) terlebih dahulu pada peserta didik, hal ini dilakukan untuk memaksimalkan waktu yang singkat sehingga tidak mengulangi lagi dari awal. Selama pembelajaran melalui daring ini lebih memfokuskan pada karakter mandiri peserta didik.

Satgas khusus PPK diberhentikan selama pandemi sehingga pelaksanaan program PPK diimplementasikan melalui guru wali kelas dengan cara memberikan materi-materi yang berkaitan dengan nilai karakter saat pembelajaran daring ataupun melalui tugas mingguan seperti sholat 5 waktu, tadarus, hafalan, tapak suci, HW atau kepramukaan, serta literasi yang dapat dilakukan oleh peserta didik secara mandiri di rumah masing-masing.

Dengan terkendala adanya pandemi covid-19 ini pembentukan karakter peserta didik memang harus ada kerjasama antara guru di sekolah, wali kelas dan orangtua siswa. Hal ini dibutuhkan ketika peserta didik mengalami perubahan kebiasaan maka interaksi wali kelas dengan orangtua siswa sangat penting untuk membantu agar peserta diik tetap berkarakter. Oleh karena itu, andil dari orang tua sangatlah berpengaruh besar dalam terciptanya PPK selama pandemi covid-19 ini.

\section{Evaluasi Hasil (Product)}

Kelima nilai karakter (religiusitas, nasionalisme, mandiri, gotong royong dan integritas) pada peserta didik secara umum belum terlaksana dengan maksimal apalagi dengan adanya pandemi saat ini. Hal ini dikarenakan transfer karakter sangat sulit dilakukan melalui pembelajaran daring. Meskipun demikian sekolah tetap berusaha untuk menyisipkan muatan-muatan karakter disetiap kegiatan pembelajaran daring.

Pengimplementasian nilai-nilai karakter peserta didik selama pandemi ini berjalan dengan baik, seperti peserta didik yang selalu melaksanakan sholat dhuha dan sholat berjamaah, mengumpulkan tugas tepat waktu, membantu orang tua di rumah, dan lain sebagainya. Perubahan karakter yang sangat terlihat selama pandemi ini yaitu kedisiplinan peserta didik.

Selama pandemi satgas khusus PPK diberhentikan tetapi ada satgas yang masih bisa dijalankan ditengah pandemi meski tidak bisa maksimal yaitu satgas Literasi. Sekolah mengikuti lomba-lomba yang berhubungan dengan literasi, salah satunya lomba bercerita di perpusda DIY yang dimana SD Muhammadiyah Karangkajen meraih juara 3. Satgas Literasi ini juga sudah beberapa kali mendapatkan juara dari lomba-lomba yang diikuti seperti lomba menulis Jawa, literasi bahasa Jawa, juara 1 provinsi, juara 3 bercerita perpusda, dan selama pandemi ini peserta didik juga menghasilkan beberapa karya seperti puisi dan cerita pendek.

Pemerintah membuat projek percontohan untuk sekolah mengadakan Pembelajaran Tatap Muka (PTM) terbatas selama pandemi dan SD Muhammadiyah Karangkajen menjadi salah satu sekolah dari 5 SD di kota Yogyakarta yang menjadi model untuk contoh PTM terbatas ini. Pelaksanaan PTM terbatas ini dilakukan dengan melaksanakan pembelajaran di kelas yang berisi sekitar 10 siswa. 


\section{Pembahasan}

\section{Tahapan Konteks (Context)}

Pada tahapan konteks dalam penelitian ini meliputi beberapa komponen yang terdiri dari visi dan misi sekolah, kebijakan sekolah, dan peluang yang dimanfaatkan dalam program PPK. Program PPK di SD Muhammadiyah Karangkajen telah memiliki kesesuaian antara yang dicanangkan oleh pemerintah dengan yang diimplementasikan. Hal ini dapat dilihat dari visi dan misi yang dimiliki oleh SD Muhammadiyah Karangkajen yang berupaya untuk mengimplementasikan pendidikan karakter dengan berbasis kelas, budaya sekolah dan masyarakat. Hal ini sesuai dengan program pemerintah yang tercantum dalam Undang-Undang No. 20 tahun 2003, agenda Nawacita Presiden Joko Widodo, dan Peraturan Presiden Republik Indonesia No. 87 Tahun 2017 tentang implementasi program Penguatan Pendidikan Karakter (PPK) di tingkat sekolah dasar.SD Muhammadiyah Karangkajen telah mengimplementasikan pendidikan berbasis karakter sesuai dengan pendapat dari Ki Hajar Dewantara yaitu olah hati (etika), olah pikir (literasi), olah karsa (estetika) dan olah raga (kinestetika).

Dari keempat nilai tersebut selanjutnya dijabarkan menjadi 18 nilai serta disarikan kedalam 5 nilai yang utama dalam pendidikan karakter, yaitu religiusitas, nasionalisme, kemandirian, gotong royong dan integritas yang menjadi satu kesatuan tidak terpisahkan sebagai identitas sekolah secara keseluruhan. Dari kelima nilai tersebut kemudian diimplementasikan di sekolah dengan memanifestasikan nilai-nilai PPK kedalam satuan tugas (Satgas Khusus PPK). Hal ini bersesuaian dengan pendapat Istantara ${ }^{21}$ yang menyatakan bahwa manajemen sumber daya manusia diperlukan untuk meningkatkan efisiensi sumber daya manusia dalam suatu organisasi.

Novitasari, berpendapat bahwa pengimplementasian nilai-nilai karakter dapat dilakukan melalui penyelenggaraan PPK dengan adanya kebijakan sekolah yang mengikat nilai- nilai tersebut dan disosialisasikan secara progresif. ${ }^{22}$ Penyelenggaraan PPK sendiri di SD Muhammadiyah Karangkajen yaitu dengan pembentukan satgas PPK yang dimana proses pembentukan tim pelatih satgas dan guru pendamping satgas dimuat dalam SK Kepala Sekolah No. 35 /KEP/III.4.AU/107/J/2020.

Selama pandemi ini penyelenggaraan PPK berbasis satgas diberhentikan di SD Muhammadiyah Karangkajen. Oleh karena itu, guru pendamping satgas dan wali kelas senantiasa berkoordinasi untuk memberikan pendidikan karakter meski melalui pembelajaran online agar sikap, watak, dan tindakan yang baik peserta didik tetap terbentuk. Hal ini sesuai dengan pendapat Busro dan Suwandi ${ }^{23}$ bahwa pendidikan

21 Dedik Tri Istiantara, "Pengembangan Manajemen Sumber Daya Manusia Berbasis Kompetensi Guna Meningkatkan Kinerja Pegawai Dan Dosen Polikteknik Perkeretaapian Indonesia," Jurnal Perkeretaapian Indonesia, 2019, https://doi.org/10.37367/jpi.v3i2.89.

22 Ririn Dwi Novitasari, Arfilia Wijayanti, and Filia Prima Artharina, "Analisis Penerapan Penguatan Pendidikan Karakter Sebagai Implementasi Kurikulum 2013," Indonesian Values and Character Education Journal 2, no. 2 (2019): 79, https://doi.org/10.23887/ivcej.v2i2.19495.

${ }^{23}$ Muhammad Busro and Suwandi, Pendidikan Karakter, 1st ed. (Yogyakarta: Media Akademi, 2017). 
karakter merupakan proses pembelajaran secara sadar untuk membentuk sikap, watak, dan tindakan baik peserta didik.

Untuk peluang yang akan dimanfaatkan dalam implementasi program PPK ini peserta didik dapat terus berprestasi, menjadi kebiasaan sampai kapan pun, dan menjadi habit (karakter) hingga di SMP-SMA-Kuliah. Hal ini sesuai dengan penelitian Gunawan yang menyatakan bahwa pendidikan karakter yaitu pendidikan yang berusaha menanamkan kebiasaan (habit) yang baik pada peserta didik agar mereka memahami hal yang benar dan salah. ${ }^{24}$

Dari uraian tersebut maka evaluasi konteks sudah sesuai dengan yang disampaikan oleh Lickona yang menekankan pada tiga hal dalam mendidik karakter, yaitu: mengetahui (knowing), mencintai (loving), dan berbuat baik (acting the good). ${ }^{25}$ Artinya jika ada kesamaan pemahaman, kecintaan akan nilai-nilai, dan perilaku yang baik satu sama lain sehingga dapat diteladani dan menjadi budaya sekolah yang unggul maka PPK akan berhasil secara keseluruhan.

\section{Tahapan Masukan (Input)}

Pada tahapan masukan dalam penelitian ini meliputi beberapa komponen yang terdiri dari program PPK, guru pendamping PPK, wali kelas, peserta didik, sarana/prasarana, dana yang mendukung, dan kondisi lingkungan sosial sekolah dan masyarakat. Pembahasan evaluasi input bahwa program itu sendiri merupakan serangkaian kegiatan terencana yang memiliki tujuan untuk memenuhikebutuhan dengan partisipasi individu atau kelompok. Hal ini sesuai dengan penelitian Munthe yang menyatakan bahwa program adalah serangkaian kegiatan yang direncanakan dengan adanya partisipasi individu atau kelompok dan memiliki tujuan untuk memenuhi kebutuhan. ${ }^{26}$

Di SD Muhammadiyah Karangkajen program PPK diimplementasikan kedalam bentuk satuan tugas (satgas) khusus PPK dalam upaya pembentukan nilai-nilai pendidikan karakter. Melalui satgas khusus PPK ini akan mempermudah penyebaran dan pengimplementasian nilai-nilai karakter secara merata dan lebih teraplikasi karena adanya pembagian tugas yang jelas. Hal ini bersesuaian dengan pendapat Hasibuan yang menyatakan bahwa dengan adanya pembagian kerja maka akan menjadi informasi tertulis yang menjelaskan tanggungjawab suatu posisi dalam organisasi. ${ }^{27}$

Guru pendamping PPK yang profesional sesuai dengan latar belakang, pengalaman dan sertifikasi pelatihan sehingga seluruh peserta didik binaannya akan mampumengimplementasikan nilai-nilai PPK dengan baik. Hal ini senada dengan pendapat

${ }^{24}$ Heri Gunawan, Pendidikan Karakter Konsep dan Implementasi (Bandung: Alfabeta, 2012).

25 Thomas Lickona, Education for Character: Mendidik Untuk Membentuk Karakter Terj. Juma Wadu Wamaungu, ed. Uyu Wahyuddin and Suryani (Jakarta: Bumi Aksara, 2012).

26 Ashiong P Munthe, "Pentingya Evaluasi Program di Institusi Pendidikan: Sebuah Pengantar, Pengertian, Tujuan dan Manfaat," Scholaria: Jurnal Pendidikan Dan Kebudayaan 5, no. 2 (2015): 1, https://doi.org/10.24246/j.scholaria.2015.v5.i2.p1-14.

27 Hasibuan, Manajemen Sumber Daya Manusia. 
Sutisna28 yang menyatakan bahwa keberhasilan pendidikan karakter di sekolah adalah dengan berbasis pada guru yang memiliki keterampilan, berwawasan luas, memiliki sikap dan kepribadian yang pantas menjadi teladan. Selama pandemi ini program PPK berbasis satgas diberhentikan sehingga guru pendamping PPK berkoordinasi dengan wali kelas yang menjadi tokoh sentral pelaksanaan PPK ditengah pandemi ini melalui pembelajaran daring. Guru wali kelas mampu mengintegrasikan karakter kedalam mata pelajaran dan mengoptimalkannya melalui muatan lokal. Hal ini sesuai dengan pendapat Putranti dan Susanti ${ }^{29}$, menyatakan bahwa pendekatan pendidikan karakter berbasis kelas melalui integrasi karakter ke dalam mata pelajaran dan mengoptimalisasikannya dengan muatan lokal.

Peserta didik yang merupakan anggota satgas tetap bersemangat untuk melaksanakan tugas dengan penuh tanggung jawab meski hanya melalui pembelajaran online. Pesertadidik yang bukan merupakan anggota satgas juga melaksanakan pembelajaran online dengan penuh semangat dan selalu bertanggungjawab untuk mengikuti pembelajaran dan mengerjakan tugas dengan tepat waktu. Hal ini bersesuaian dengan pendapat Anshari ${ }^{30}$ bahwa karakter pada peserta didik merupakan hasil interaksi antara pembawaan dan lingkungannya.

Untuk mewujudkan kelancaran dan kedinamisan suatu kegiatan maka hendaklah didukung dengan ketersediaan sarana dan prasarana yang memadai. Hal ini bersesuaian dengan pendapat Lickona ${ }^{31}$ yang menyatakan bahwa salah satu indikator keberhasilan pendidikan karakter adalah adanya manajemen kelas dan sekolah yang handal. Salah satu kunci utama pengelolaannya adalah kelengkapan sarana dan prasarana yang memadai, serta kekuatan finansial untuk mendukung kegiatan tersebut.

Untuk pembiayaan dana berbagai kegiatan program PPK di SD Muhammadiyah Karangkajen dengan melibatkan berbagai pihak seperti bantuan dana dari pemerintah dan sumbangan orang tua siswa sehingga kegiatan dapat berjalan dengan baik. Hal ini sesuai dengan penelitian dari Andriani et al., ${ }^{32}$ yang mengatakan bahwa faktor pendukung pada program PPK salah satunya adalah pendanaan kegiatan yang bersangkutan.

Selanjutnya kondisi lingkungan sosial sekolah dan masyarakat juga menjadi faktor penentu terselenggaranya program PPK ini dengan baik. Hal ini bersesuaian dengan

28 Deni Sutisna, Dyah Indraswati, and Muhammad Sobri, "Keteladanan Guru Sebagai Sarana Penerapan Pendidikan Karakter Siswa," JPDI (Jurnal Pendidikan Dasar Indonesia) 4, no. 2 (2019): 29, https://doi.org/10.26737/jpdi.v4i2.1236.

${ }_{29}$ Yustina Putranti and Maria Melani Ika Susanti, "Penerapan Program Penguatan Pendidikan Karakter Berbasis Kelas di Sekolah Dasar Se-Kecamatan Sleman Kabupaten Sleman,” Elementary Journal 2, no. 1 (2019): 42-52.

30 Isa Anshori, "Penguatan Pendidikan Karakter Di Madrasah," Halaqa: Islamic Education Journal 1, no. 2 (2017): 11, https://doi.org/10.21070/halaqa.v1i2.1243.

${ }^{31}$ Lickona, Education for Character: Mendidik Untuk Membentuk Karakter Terj. Juma Wadu Wamaungu.

32 Silvya Eka Andriani, Imron Arifin, and Ahmad Nurabadi, "Implementasi Program Penguatan Pendidikan," Jurnal Administrasi Dan Manajemen Pendidikan 1 (2018): 238-44. 
pendapat dari Suprio et al. ${ }^{33}$, yang menyatakan bahwa melalui pendekatan berbasis budaya sekolah akan mampu membentuk karakter peserta didik melalui kegiatan rutin dan terprogram di sekolah hingga menjadi suatu kebiasaan. Pembentukan karakter tidak hanya dimulai dari sekolah saja tapi juga ada keterkaitan antara keluarga dan masyarakat. Di SD Muhammadiyah Karangkajen sendiri lingkungan sekolah dan masyarakat mendukung adanya program PPK. Hal ini sesuai dengan pendapat Lickona ${ }^{34}$ yang menyatakan bahwa pendidikan karakter akan berjalan efektif dengan menciptakan komunitas sekolah yang penuh perhatian serta melibatkan keluarga dan masyarakat sebagai mitra.

\section{Tahapan Proses (Process)}

Pada tahapan proses dalam penelitian ini meliputi komponen yang terdiri dari proses pelaksanaan program PPK. Pada evaluasi proses akan membahas tentang kesesuaian rincian pelaksanaan program PPK selama pandemi dengan realita yang telah dilaksanakan. Proses pembentukan nilai karakter senantiasa berpedoman pada perencanaan yang matang, pelaksanaan yang konsekuen dan evaluasi yang obyektif. Hal ini bersesuaian dengan penelitian dari Miharja et al., ${ }^{35}$ yang menyatakan bahwa evaluasi dalam penguatan karakter melalui tahap perencanaan, monitoring, pelaksanaan, dan tindaklanjut.

Aktivitas pelaksanaan program PPK selama pandemi telah menunjukkan kesesuaian antara yang direncanakan dengan realita di lapangan. Hal ini dapat tercapai karena proses pengimplementasian nilai karakter dilakukan dengan menyispkan nilai-nilai karakter melalui proses pembelajaran daring secara bertahap dan terus menerus sehingga karakter yang dihasilkan akan melekat pada diri peserta didik. Hal ini bersesuaian dengan pendapat Gunawan $^{36}$ yang menyampaikan bahwa pengembangan karakter dalam sistem pendidikan merupakan kesinambungan antara komponen karakter yang mengandung nilai perilaku yang diterapkan secara bertahap.

Adanya peran guru pendamping dan wali kelas yang senantiasa mendukung, memotivasi dan menasehati peserta didik sehingga akan membentuk karakter yang tumbuh dan berkembang secara alami tanpa adanya paksaan yang terimplikasikan dalam karakter atau akhlak peserta didik. Hal ini bersesuaian dengan pendapat dari Lickona ${ }^{37}$ yang menyatakan bahwa dengan usaha mendorong motivasi diri peserta didik serta memberikan kesempatan kepada peserta didik untuk melakukan tindakan moral.

Selama pandemi covid-19 ini komunikasi dua arah yang dibangun sekolah dengan orangtua siswa sangat membantu dalam pelaksanaan program PPK. Komunikasi tersebut dilakukan agar orangtua siswa juga memahami peran yang utama dalam memotivasi dan

33 Achmad Bagus Suprio, Fattah Hanurawan, and Sutarno, "Keterampilan Sosial Siswa Sekolah Dasar dalam Penguatan Pendidikan Karakter Berbasis Budaya Sekolah," Jurnal Pendidikan: Teori, Penelitian, dan Pengembangan 5, no. 1 (2020): 121-26.

${ }^{34}$ Lickona, Education for Character: Mendidik Untuk Membentuk Karakter Terj. Juma Wadu Wamaungu.

35 Fuad Jaya Miharja et al., "Evaluasi Program Penguatan Karakter : Studi Di Sekolah Non- Piloting Ppk Di Kota Malang Evaluation of Strengthening Character Programme : Study in Non-” 1660 (2020).

${ }^{36}$ Gunawan, Pendidikan Karakter Konsep dan Implementasi.

37 Lickona, Education for Character: Mendidik untuk Membentuk Karakter Terj. Juma Wadu Wamaungu. 
mendukung kegiatan dari internal keluarga. Pendapat dari Subianto ${ }^{38}$ menyampaikan bahwa lingkungan rumah dan keluarga memiliki andil yang sangat besar terhadap pembentukan perilaku anak sehingga mereka memiliki tanggungjawab dalam hal ini.

Dengan dukungan dari orang tua yang begitu peduli dengan anaknya sangat menentukan terimplementasikanya program dengan baik terutama ditengah pandemi seperti sekarang ini. Subianto ${ }^{39}$ menyatakan intensitas kebutuhan anak untuk mendapatkan bantuan dari orang tua menjadi pengembangan dasar-dasar kreativitas diri pada anak.

\section{Tahapan Produk (Product)}

Pada tahapan produk dalam penelitian ini meliputi komponen yang terdiri dari implementasi nilai-nilai PPK. Pendidikan karakter pada hakikatnya adalah untuk membentuk bangsa yang tangguh, berdaya saing, berakhlak mulia, beretika, toleran, gotong royong, berjiwa patriotik, dan dinamis yang dilandasi oleh keimanan dan ketaqwaan kepada Tuhan Yang Maha Esa dengan berlandaskan Pancasila. Nilai karakter yang lebih ditonjolkan di SD Muhammadiyah Karangkajen selama pandemi covid-19 yaitu nilai religiusitas dan kemandirian.Nilai religiusitas merupakan pengimplementasian sikap dan perilaku sesuai syariat agama seperti selalu melaksanakan sholat 5 waktu, melaksanakan sholat dhuha, tadarus, menjaga ucapan maupun perbuatan, dan lain sebagainya. Hal ini sesuai dengan pendapat Tim penyusun $\mathrm{PPK}^{40}$ yang menjelaskan bahwa nilai religiusitas merupakan perwujudan ketaatan manusia kepada Allah SWT yang diwujudkan dalam sikap dan perilaku penerapan hukum Islam.

Nilai kemandirian merupakan sikap peserta didik untuk tidak bergantung kepada orang lain. Kemandirian merupakan pilar yang utama dalam membentuk kemampuan personal peserta didik terutama ditengah pandemi seperti sekarang ini. Penerapan nilai kemandirian seperti selalu mengerjakan tugas tepat waktu, mengikuti pembelajaran online tepat waktu, membantu orangtua di rumah, dan lain sebagainya. Hal ini bersesuaian dengan penelitian Kusnoto ${ }^{41}$ yang menyatakan bahwa nilai karakter mandiri merupakan sikap dan perilaku tidak bergantung pada orang lain dan senantiasa bekerja keras dengan usaha sendiri.

Nilai-nilai PPK telah terimplementasikan di lingkungan SD Muhammadiyah Karangkajen. Ini menjadi landasan karena menurut Rosad ${ }^{42}$ karakter akan dapat dinilai keberhasilanya apabila mampu diintegrasikan kedalam kegiatan sehari-hari. Hal ini terlihat dari sikap dan perilaku peserta didik yang menjadi target program PPK. Hasil observasi di

\footnotetext{
38 Jito Subianto, "Peran Keluarga, Sekolah, dan Masyarakat dalam Pembentukan Karakter Berkualitas," Edukasia: Jurnal Penelitian Pendidikan Islam 8, no. 2 (2013): 331-54, https://doi.org/10.21043/edukasia.v8i2.757.

39 Subianto.

40 Tim Penyusun PPK, Pedoman Penilaian Penguatan Pendidikan Karakter Tingkat Sekolah Dasar dan Sekolah Menengah Pertama (Jakarta: Kementerian Pendidikan dan Kebudayaan Republik Indonesia, 2016).

41 Yuver Kusnoto, "Internalisasi Nilai-Nilai Pendidikan Karakter pada Satuan Pendidikan," Jurnal Pendidikan Sosial, 2017.

42 Ali Miftakhu Rosad, “Implementasi Pendidikan Karakter melalui Managemen Sekolah," Tarbawi: Jurnal Keilmuan Manajemen Pendidikan 5, no. 02 (2019): 173, https://doi.org/10.32678/tarbawi.v5i02.2074.
} 
lapangan terkait dengan keberhasilan program PPK dalam mengimplementasikan program PPK saat kegiatan PTM (Pembelajaran Tatap Muka) terbatas sebagai berikut: a) dalam nilai religiusitas telah terimplementasikanya secara merata nilai religiusitas. Hal ini ditunjukkan saat pelaksanaan kegiatan PTM terbatas peserta didik membiasakan salam jika bertemu dengan guru, berdoa sebelum memulai pembelajaran, dan bertutur kata serta bersiap baik dengan guru dan b) nilai kemandirian yang telah terimplementasikan di lingkungan sekolah. Hal ini ditunjukkan dengan sikap peserta didik yang mengikuti arahan tanda yang ada di sekolah saat memasuki sekolah menuju kelas untuk mengurangi interaksi dengan yang lain, membawa handsanitizer sendiri, mencuci tangan dengan sabun, dan mengerjakan tugas dengan penuh tanggung jawab. Dengan nilai kemandirian ini maka akan membentuk jiwa kepemimpinan peserta didik sejak dini.

Dari penjelasan tersebut maka penelitian ini telah dapat membuktikan bahwa implementasi program PPK selama pandemi covid-19 yang merupakan manifestasi dari 5 dasar nilai PPK yaitu (religiusitas, nasionalisme, kemandirian, gotong royong dan integritas) dengan lebih menonjolkan nilai religiusitas dan kemandirian yang dapat terimplementasikan dengan baik di lingkungan rumah dan sekolah. Hal ini juga dapat diimplementasikan di sekolah yang lainnya sesuai dengan kondisi sekolah setempat sehingga mampu untuk mengimplementasikan nilai-nilai PPK dengan lebih baik.

Hal ini sesuai dengan pendapat dari Lickona ${ }^{43}$ pendidikan karakter dapat berjalan secara efektif jika para pendidik dan pemangku kebijakan pendidikan memperhatikan serta melaksanakan prinsip-prinsip berikut: 1)nilai-nilai etika inti hendaknya dikembangkan, sementara nilai-nilaikinerja pendukungnya dijadikan sebagai dasar atau fondasi; 2) karakter hendaknya didefinisikan secara komprehensif, sehingga mencakup pikiran, perasaan, dan perilaku; 3) pendekatan yang digunakan hendaknya komprehensif, disengaja, dan proaktif; 4) ciptakan komunitas sekolah yang penuh perhatian; 5) beri peserta didik kesempatan untuk melakukan tindakan moral; 6) buat kurikulum akademik yang bermakna dan menantang yang menghormati semua peserta didik, mengembangkan karakter, dan membantu mereka untuk berhasil; 7) usahakan mendorong motivasi diri peserta didik; 8) libatkan staf sekolah sebagai komunitas pembelajaran dan moral; 9) tumbuhkan kebersamaan dalam kepemimpinan moral; 10) libatkan keluarga dan anggota masyarakat sebagai mitra; serta 11) evaluasi karakter sekolah, fungsi staf sekolah sebagai pendidik karakter, dan sejauh mana anak didik dimanifestasikan karakter yang baik.

\section{PENUTUP}

\section{Simpulan}

Berdasarkan evaluasi pelaksanaan program Penguatan Pendidikan Karakter (PPK) selama pandemi di SD Muhammadiyah Karangkajendidapatkan hasil: 1) evaluasi konteks telah memiliki kesesuaian antara pelaksanaan program PPK dengan visi dan misi sekolah

\footnotetext{
${ }^{43}$ Lickona, Education for Character: Mendidik untuk Membentuk Karakter Terj. Juma Wadu Wamaungu.
} 
serta SK kepala sekolah tentang pelaksanaan program PPK. Peluang dari program ini dapat membentuk pembiasaan menjadi habit (karakter) sehingga terbukti berhasil mengimplementasikan nilai-nilai PPK; 2) evaluasi input program PPK menunjukkan sarana prasarana, anggaran $\mathrm{RAB}$, dan kondisi lingkungan di sekolah telah mendukung pelaksanaan program PPK sehingga memaksimalkan dalam pelaksanaan kegiatan PPK. Guru pendamping PPK berkoordinasi dengan wali kelas dan guru mata pelajaran dalam mengimplementasikan nilai-nilai karakter selama pembelajaran online sehingga program PPK tetap berjalan ditengah pandemi covid-19; 3) evaluasi proses pelaksanaan program PPK selama pandemi telah sesuai rincian pelaksanaan program dengan realita di lapangan serta standar yang telah ditetapkan kepala sekolah dan tim PPK; dan 4) evaluasi produk telah terimplementasikannya nilai-nilai PPK selama pandemi terutama nilai religiusitas dan nilai kemandiriandimana karakter mandiri, disiplin dan tanggung jawab peserta didik terbukti meningkat.

\section{Saran}

Saran dari peneliti pelaksanaan program penguatan pendidikan karakter di sekolah dasar dapat terus terjadi. Selain itu diharapakn agar dengan penguatan pendidikan karakter di sekolah dasar dapat membentuk leader school by student to student dalam mengimplementasikan dan memanifestasikan nilai-nilai karakter kedalam berbagai aspek kehidupan.

\section{E. DAFTAR PUSTAKA}

Agus, Wibowo. "Pendidikan Karakter: Strategi Membangun Karakter Bangsa Berperadaban." Yogyakarta: Pustaka Pelajar, 2012.

Andriani, Silvya Eka, Imron Arifin, dan Ahmad Nurabadi. "Implementasi Program Penguatan Pendidikan." Jurnal Administrasi Dan Manajemen Pendidikan 1 (2018): 238-44.

Anggraeni, Rise Aditya, and Soedjono Soedjono. "Implementasi Program Penguatan Pendidikan Karakter (Ppk) di SDN Mangkang Wetan 02 Kota Semarang." GEMA PUBLICA, 2018. https://doi.org/10.14710/gp.3.1.2018.36-45.

Anshori, Isa. "Penguatan Pendidikan Karakter di Madrasah." Halaqa: Islamic Education Journal 1, no. 2 (2017): 11. https://doi.org/10.21070/halaqa.v1i2.1243.

Busro, Muhammad, and Suwandi. Pendidikan Karakter. 1st ed. Yogyakarta: Media Akademi, 2017.

Depdiknas. Undang-Undang No. 20 Tahun 2003 tentang Sistem Pendidikan Nasional. Jakarta, 2003.

Gunawan, Heri. Pendidikan Karakter Konsep dan Implementasi. Bandung: Alfabeta, 2012.

Hamid, A. Pendidikan Karakter Berbasis Pesantren: Pelajar dan Santri Dalam Era IT \& Cyber Culture. Surabaya: IMTIYAZ, 2017.

Hasibuan. Manajemen Sumber Daya Manusia. Jakarta: Bumi Aksara, 2007.

Hasirun, La, Djoko Suryo, dan Taat Wulandari. "From Papua Ethnonationalism to Indonesian Nationalism: A Historical Study." In Proceedings of the 1st International Conference on Science and Technology for an Internet of Things. European Alliance for Innovation (EAI), 2018. 
Hikmawati, A., H. Sawiji, dan A. Subarno. "Pembagian Kerja, Motivasi Kerja dan Kemampuan Kerjasama terhadap Efektivitas Kerja Pegawai." Jurnal Pendidikan Administrasi Perkantoran, 2012.

Istiantara, Dedik Tri. "Pengembangan Manajemen Sumber Daya Manusia Berbasis Kompetensi guna Meningkatkan Kinerja Pegawai Dan Dosen Polikteknik Perkeretaapian Indonesia." Jurnal Perkeretaapian Indonesia, 2019. https://doi.org/10.37367/jpi.v3i2.89.

Kemendikbud. Kajian dan Pedoman Penguatan Pendidikan Karakter. Jakarta: Kementerian Pendidikan dan Kebudayaan, 2016.

- - - Konsepd Dan Pedoman Penguatan Pendidikan Karakter. Jakarta: Kementerian Pendidikan dan Kebudayaan, 2017.

Kementrian Kesehatan RI. "Kesiapsiagaan Menghadapi Infeksi COVID-19." https://www.kemkes.go.id/article/view/20030400008/FAQ-Coronavirus.html, 2020.

Khotimah, Desy Nurlaida. "Implementasi Program Penguatan Pendidikan Karakter ( PPK ) melalui Kegiatan 5s Di Sekolah Dasar." Ilmiah Kependidikan 2, No. 1 (2019): 28-31.

Koesoema D. Pendidikan Karakter Berbasis Kelas. Yogyakarta: PT Kanisius, 2018.

Kusnoto, Yuver. "Internalisasi Nilai-nilai Pendidikan Karakter psda Satuan Pendidikan." Jurnal Pendidikan Sosial, 2017.

Lickona, Thomas. Education for Character: Mendidik untuk Membentuk Karakter Terj. Juma Wadu Wamaungu. Edited by Uyu Wahyuddin and Suryani. Jakarta: Bumi Aksara, 2012.

Miharja, Fuad Jaya, Adi Slamet Kusumawardana, Arif Setiawan, Prodi Pendidikan Biologi, Universitas Muhammadiyah Malang, Prodi Pendidikan Matematika, Universitas Muhammadiyah Malang, and Universitas Muhammadiyah Malang. "Evaluasi Program Penguatan Karakter: Studi di Sekolah Non- Piloting Ppk di Kota Malang Evaluation of Strengthening Character Programme : Study in Non-" 1660 (2020).

Munthe, Ashiong P. "Pentingya Evaluasi Program di Institusi Pendidikan: Sebuah Pengantar, Pengertian, Tujuan dan Manfaat." Scholaria: Jurnal Pendidikan Dan Kebudayaan 5, no. 2 (2015): 1. https://doi.org/10.24246/j.scholaria.2015.v5.i2.p1-14.

Muryaningsih, Sri, dan Ali Mustadi. "Pengembangan RPP Tematik-Integratif untuk Meningkatkan Karakter Kerja Keras di Kelas 1 SDN 2 Sokaraja Tengah.” Jurnal Prima Edukasia, 2015. https://doi.org/10.21831/jpe.v3i2.6146.

Novitasari, Ririn Dwi, Arfilia Wijayanti, dan Filia Prima Artharina. "Analisis Penerapan Penguatan Pendidikan Karakter Sebagai Implementasi Kurikulum 2013." Indonesian Values and Character Education Journal 2, No. 2 (2019): 79. https://doi.org/10.23887/ivcej.v2i2.19495.

Nurbaiti. "Kecanduan Bermain Game Online Dan Hubungannya dengan Pendidikan Karakter Islami Siswa (Studi Di Sd Azhari Cilandak Jakarta)" 3, No. 1 (2020): 55-67.

Onde, Mitrakasih La ode, Hijrawatil Aswat, Fitriani B, dan Eka Rosmitha Sari. "Integrasi Penguatan Pendidikan Karakter (PPK) Era 4.0 pada Pembelajaran Berbasis Tematik Integratif di Sekolah Dasar." Jurnal Basicedu, 2020. https://doi.org/10.31004/basicedu.v4i2.321.

Putranti, Yustina, dan Maria Melani Ika Susanti. "Penerapan Program Penguatan Pendidikan Karakter Berbasis Kelas di Sekolah Dasar Se-Kecamatan Sleman Kabupaten Sleman." Elementary Journal 2, No. 1 (2019): 42-52.

Putri, Dini Palupi. "Pendidikan Karakter pada Anak Sekolah Dasar di Era Digital." AR-RIAYAH: Jurnal Pendidikan Dasar, 2018. https://doi.org/10.29240/jpd.v2i1.439.

Rosad, Ali Miftakhu. "Implementasi Pendidikan Karakter melalui Managemen Sekolah." Tarbawi: 
Jurnal Keilmuan Manajemen Pendidikan 5, No. $02 \quad$ (2019): 173. https://doi.org/10.32678/tarbawi.v5i02.2074.

Santika, I Wayan Eka. "Pendidikan Karakter pada Pembelajaran Daring." Indonesian Values and Character Education Journal 3, No. 1 (2020): 8-19.

Subianto, Jito. "Peran Keluarga, Sekolah, dan Masyarakat dalam Pembentukan Karakter Berkualitas." Edukasia: Jurnal Penelitian Pendidikan Islam 8, No. 2 (2013): 331-54. https://doi.org/10.21043/edukasia.v8i2.757.

Sujatmiko, Ilham Nur, Imron Arifin, dan Asep Sunandar. "Penguatan Pendidikan Karakter di SD." Jurnal Pendidikan: Teori, Penelitian, Dan Pengembangan, 2019.

Suprio, Achmad Bagus, Fattah Hanurawan, and Sutarno. "Keterampilan Sosial Siswa Sekolah Dasar dalam Penguatan Pendidikan Karakter Berbasis Budaya Sekolah." Jurnal Pendidikan: Teori, Penelitian, Dan Pengembangan 5, No. 1 (2020): 121-26.

Sutisna, Deni, Dyah Indraswati, dan Muhammad Sobri. "Keteladanan Guru sebagai Sarana Penerapan Pendidikan Karakter Siswa." JPDI (Jurnal Pendidikan Dasar Indonesia) 4, no. 2 (2019): 29. https://doi.org/10.26737/jpdi.v4i2.1236.

Tim Penyusun PPK. Pedoman Penilaian Penguatan Pendidikan Karakter Tingkat Sekolah Dasar dan Sekolah Menengah Pertama. Jakarta: Kementerian Pendidikan dan Kebudayaan Republik Indonesia, 2016.

Windasari, Dewi, dan Mohammad Syahidul Haq. "Program Ready To Be a Leader Di Sd Al-Falah Darussalam Tropodo Sidoarjo" 08, No. 20 (2020): 267-78. 
144| ibriez | Iunal Lependidikan Dasar $\mid$ Vol 6 No 2 Tahun 2021 